\title{
Perils of Entrepreneurial Philanthropy in Higher Education
}

\author{
James C Wetherbe (Texas Tech University)
}

\author{
KEYWORDS: Educational Services, Entrepreneurship, \\ Leadership.
}

A successful entrepreneur and his family wanted to donate a new building to a state university. What happened next illustrated the maxim that "no good deed goes unpunished."

Because the building was part of a state institution (and all that implies), the original construction estimates quickly ballooned into a project that cost $50 \%$ more than a similar commercial project. Stunned, the alum nevertheless agreed to increase his donation. A month after the building plans were unveiled with great fanfare, the cost to complete the building nearly doubled again, because the university's architect greatly embellished the design.

With a price tag now significantly higher than agreed to at the ground breaking, the donor faced some difficult options. He could dramatically increase his gift again, force an uncooperative architect to redo the design, cancel the gift with embarrassment, or recruit additional donors. He eventually retained and worked with another architect to come up with a new design, which exceeded the budget by only $4 \%$. While the building was a huge success, the entrepreneur learned a tough lesson on the perils of philanthropy.

Higher education has benefited greatly from entrepreneurs' largesse -- from entire universities funded by the Stanford, Rockefeller and Vanderbilt families, to endowed professorships, to many thousands of smaller contributions that help deserving students pay tuition. But many benefactors have learned to their dismay that their good intentions can backfire. Building costs mushroom out of control; university fundraisers deduct a commission from the gift; university leaders divert the donation to other projects or needs.

I've seen this happen, from the inside and the outside. l've been a professor, a university administrator/fundraiser and an entrepreneur. I have personally donated scholarships, professorships, excellence endowments, lecture hall/conference rooms,

faculty offices and a chapel.

My message for goodhearted entrepreneurs: be aware of what can go wrong. Don't trust your heart, your friends or the university development officers. Most importantly, do your homework before you open your wallet to give back.

\section{Entrepreneurs are Enthusiastic Benefactors}

The Chronicle of Philanthropy's annual corporate giving survey reveals that companies led by entrepreneurs allocate more than twice the percentage of profits to charity than many of America's largest companies. From the Gates Foundation and its focus on human health, to the $\$ 100$ million that Facebook's Mark Zuckerberg donated to Newark's public schools, many wildly successful entrepreneurs are giving back to the world.

In fact, this web site, EIX.org(https://eiexchange.com/) (https://eiexchange.com/), is possible because of entrepreneur Richard Schulze, founder of Best Buy, through the The Richard M. Schulze Family Foundation. Schulze aspires to help more entrepreneurs succeed through providing EIX.org(https://eiexchange.com/) (https://eiexchange.com/) as a free learning resource to professors, students and practitioners of entrepreneurship. Successful entrepreneurs, he reasons, create more jobs and improve the economy and society.

The primary motivation for this entrepreneurial philanthropy? It is a belief in "giving back" as an individual and a desire to encourage that philosophy within the corporate culture, according to a 2010 study conducted by Fidelity Investments ${ }^{\circledR}$ Charitable Gift Fund. But the Fidelity study also revealed that more than half of entrepreneurs rely on their own judgment or the advice of those closest to them about donations, including best practices.

This practice can lead to unanticipated and undesired 
outcomes, especially at universities. Here are some common types of gifts to higher education and the problems that can happen with each.

\section{Scholarships}

Scholarships are one of the most popular and straightforward gifts. They can be as simple as a onetime scholarship or can be a recurring scholarship that can last forever or as long as the donor wants. But what many donors don't realize is that universities frequently take a "donation fee" of roughly $5 \%$ off the gift to support development and fundraising costs, even if the entrepreneur initiated the gift without involving the development staff. This means the scholarship will have to earn that $5 \%$ back before it can be awarded, or the donor, often to his or her surprise and dismay, will need to pay the administrative fee separately.

Some entrepreneurs create scholarship endowments, named for the donor or another person or company, where interest earned from the endowment funds one or more scholarships year after year. The challenge here is that the university may change its academic offerings and its structure in the future. For example, a scholarship for entrepreneurship students in the college of business may need to be broadened if entrepreneurship becomes a standalone major, apart from the business school.

A more common issue is that over time the university doesn't honor the full intent of the gift. For example, one entrepreneur created a multimillion-dollar endowment to pay for all four years of college for several students on an ongoing basis. New students are awarded scholarships each year. The donor specified that he wanted all scholarship students to write a letter every year updating his family on their academic progress. This was honored for several years, but after a change in fundraising staff it stopped. The new staff didn't care about resolving the problem, stating that university policy required students to write only one letter thanking the donor. Because they didn't see the entrepreneur as a source of future gifts, the fundraisers felt they could afford to ignore him.

They were wrong. The entrepreneur had made provision in his will for a final multi-million dollar gift to the university. He cancelled it.

\section{Professorships}

Endowed, named professorships are a powerful way to allow a university to recruit and retain top talent, which is key to developing top academic programs. Professorships typically require a minimum endowment of $\$ 500,000$, while endowed chaired professorships typically start at $\$ 1$ million and can go several million higher. These endowments have been popular gifts among successful entrepreneurs.

One key issue is that many donors don't help choose the professors who will benefit from their largesse. This deprives the entrepreneur, the professor and the university of the chance to explore working relationship possibilities that can lead to additional funding for programs and research.

Another challenge is that the donor can't be sure the professorship will continue to serve its original purpose. Though most universities have periodic reviews (for example, every three years) to evaluate performance and renew the professorship, donors don't often participate, so they never know if their original intent is being honored. Most universities also want to craft language that allows them to repurpose the professorship to another academic discipline once the professor retires or after a specified number of years, if they consider it in the best interests of the university. The donor may have no say when this happens.

Maximum term limits for the professorship, regardless of performance, can also blunt the donor's vision. One entrepreneur donor endowed a $\$ 2$ million chair and was convinced to limit the professorship to a maximum of 15 years. After the 15 years passed, the donor was very satisfied with the incumbent and wanted to keep the professorship going for another five years. However, after a year of correspondence exchanges, the institution refused his request as they had a recruiting agenda that differed from the donor. The donor was not given the opportunity to participate in the interview of the new professor, as he had previously.

The entrepreneur, who had previously donated over $\$ 10$ million, gave no more gifts to this university.

\section{Named Colleges and Programs}

Program endowments are aimed a supporting a specific college, academic or program initiative. For example, an entrepreneur donor might want an ongoing student competition for entrepreneurial concepts, where students receive seed money for winning ideas. The challenge is making sure that the program intent doesn't 
wander off course in the future.

How far can it stray? A lot.

One entrepreneur created an excellence award endowment for the dean of the business school to provide financial awards to faculty, students, staff and alumni who provided service to the university above and beyond the call of duty. Over the years the endowment turned into an investment fund so students majoring in finance could practice real-life investing. The awards were discontinued.

Endowing a college can cost $\$ 25$ million or more. The revenue from the endowment can be used for a diverse variety of funding, including professorships, scholarships and research/instructional programs. This presents the largest challenge in ensuring funds are used in what will be a variety of ways as intended.

\section{Buildings and Facilities}

These are the largest and most prestigious gifts and as no surprise the most unwieldy. The example at the beginning of this article illustrates the problem well. The biggest danger comes when the university publicizes the gift, then determines that the original funding won't be enough to complete the project or "after the fact" addons.

Other issues can crop up years after the gift was bestowed. What happens when a building or facility is no longer used for its original intent? If a donor wants the business school named for a company or individual, does the old building retain the name now that it's housing media and communications, after the business school moved to new quarters?

Recently, when a business school building was expanded, an endowed facility within in it vanished due to the new configuration. Should that facility be replaced with a new room or does the gift disappear? In this case, the university offered the donor several acceptable options for re-naming purposes. But what would have happened if the donor had been deceased?

\section{Overcoming the Challenges}

Though different categories of gifts create unique challenges and risks, donors can take these steps to help ensure that their money is used for its intended purpose.

\section{Fees Can be Negotiated}

Gift donation fees were discussed earlier. Standard donor agreements do not allow exceptions. They often include fees that eat into the original value of the gift. For example, at some colleges $5 \%$ of a gift automatically goes to the development staff office as a "finders fee," even if the donor initiated the gift and the staff had nothing to do with finding it. "Administration fees," sometimes $1 \%$ of the annual revenue of the endowment, take another chunk and can be increased at the university's discretion....and used for other purposes.

For example, a donor wants to create a scholarship fund for students of entrepreneurship. He or she approaches the university with the idea. The university development staff, though having done no fundraising for this gift, will take $5 \%$ of the gift as revenue. The university may also take $1 \%$ each year from the endowment's value to use as they choose. If a conservatively invested endowment earns only $5 \%$, this means $20 \%$ of what is paid out does not go to scholarships.

Donors are often unaware these fees can be negotiated. For example, for an unsolicited gift a donor should put in writing that reduced or no fees be extracted from the endowment or its earnings. These negotiations should take place before the gift is given, while the donor has leverage.

\section{Build in Flexibility Where Needed}

Sometimes programs and schools change within a university over the years. For example, as mentioned above, a university may spin off its entrepreneurship program into its own school, creating problems if the donor originally specified that an entrepreneurship scholarship goes to a student in the business school.

The language within the gift document should not be so restrictive that it creates problems if this happens, although it should be firm that the scholarship must go to an entrepreneurship student.

\section{Beware the Changing of the Guard}

A wonderful camaraderie and trusting relationships usually develop between university fundraisers and donors. They often have verbal understandings about how a gift should be used, apart from the official language that appears in the written agreement. Donors don't think about writing these wishes down because they were communicated to trusted, good friends. 
What happens when the trusted friends retire or leave? While the donor might remember those verbal agreements, the university can easily forget. The new development staff, understandably, is most interested in new gift possibilities and can be dismissive of verbal agreements made years ago by others no longer in power. Don't trust the university to remember your wishes if they are not written down.

\section{Leverage: More Effective than the Law}

Even clear documentation does not ensure a gift will always be used in the manner that was intended, as the "self-interest" of those within the academia can conflict with honorable intentions. Universities can often get away with blatant breaching of longstanding donor agreements, and the breach goes unchallenged because the original donor is deceased. Institutions outlive people.

Frederic Fransen, founder of Donor Advising, Research \& Education Services, which helps negotiate gifts to colleges, is outspoken on the problem.

"One of the reasons universities like perpetual endowments is they provide a way of laundering restricted gifts into unrestricted funds through their high and often hidden [administrative] fees," he wrote in a 2011 Philanthropy Daily article.

Take, for example, a $1 \%$ charge to the average market values of pooled endowment funds. One percent may seem small, but not in the context of endowments worth millions and billions. Such a fee can grow very large after a few years-without incurring any obligation to serve the donors' purposes. It can be used for whatever the school wants.

Believe it or not, even donors who notice this have little recourse. Both donors and universities shy away from lawsuits that can damage their image. Moreover, public universities have immunity from most lawsuits, including those for breach of contract anyway. And immunity means: "Never having to say you're sorry."

The most powerful tool is leverage, which gives donors the power to cut off future largesse. Just as smart individuals study administrative expenses of charities they might support, donors should look at universities' fees and fundraising expenses. They should avoid supporting or cut off support from those that divert too much money from the intended recipients.

\section{Legal Advice?}

Most donor agreements are brief -- some are only about a page long -- but when a huge donation is involved it still may be worth involving an attorney. Many donors who are excited about funding a university and its mission may see lawyers as a real buzz-kill, like a prenuptual agreement. However, getting legal advice gives the entrepreneur time to cool down, get beyond his or her idealism, and really think about the fine points of the gift and how the university handles it. An attorney can also serve as the designated bad guy if the donor agreement includes language about fees or restrictions that lessen the impact of the investment. And having an attorney go over the terms of the agreement also puts the university on notice that you care about the longterm legacy of the gift.

One sobering thought: even with an ironclad contract, universities have immunity in legal disputes. And as a practical matter, any public contention about a gift, legal or otherwise, can disparage the legacy of the donor and defeat a major purpose of philanthropy. But a university that breaches an agreement with a donor risks publicity that will drive away other potential donors, so the chance of a public dispute is less likely.

\section{Set up a Foundation}

Foundations take more effort but can solve many of the aforementioned problems. Rather than donate directly to the university, a donor can create a foundation that supports scholarships, professorships and programs. In this scenario, the funds remain within the control of the donor and his or her heirs, and the foundation can stop supporting the university if it misuses the money.

Examples of this in the entrepreneurship world include the Kaufman Foundation and the Richard M. Schulze Family Foundation. Though Dick Schulze has directly funded the Schulze School of Entrepreneurship at the University of St. Thomas, his foundation also funds professorships at other universities. These professorships are designated for three-year renewable terms and provide $\$ 50,000$ annually to support the research of up-and-coming entrepreneurship professors.

Through this funding approach there are no university development fees and the intent of the gift is protected.

\section{Conclusion}

The generosity of entrepreneurs is a powerful force in 
society and has greatly enhanced higher education.

As powerful as entrepreneurial philanthropy can be, it is important to retain the mindset of an entrepreneur when being philanthropic. Effective philanthropy is not about writing large checks. Rather it is about creating a working relationship and documentation that honors the entrepreneur's vision and leads to a meaningful outcome that would otherwise not have occurred. By being careful about protecting their gifts from forces that can erode value, entrepreneurs can help ensure their intentions are always respected.

And remember the words of industrialist Andrew Carnegie: "It is more difficult to give money away intelligently than to earn it in the first place." 